\title{
Social media influencer and brand loyalty on generation Z: the mediating effect of purchase intention
}

\author{
Puput Alvhyona Pinto ${ }^{1}$ and Eristia Lidia Paramita1 \\ ${ }^{1}$ Department of Management, Faculty of Economics, Universitas Kristen Satya Wacana, Indonesia
}

\begin{abstract}
Influencer marketing has become a new method of promoting a product or brand. The marketers believe that implementing influencer marketing appropriately may form a positive customer view of a product or brand so it can bring customers loyalty on the brand. This study aims to investigate the effect of influencers on brand loyalty of Generation $Z$ with purchase intention as a mediating variable. Generation $Z$ is a generation that is very close to technology even most of their life is spent to playing with social media. By expecting a marketing strategy that is close and easily accessible to generation $Z$, can create purchase intentions and loyalty at lower cost. The population is the Instagram users in Indonesia. Purposive sampling was used in this study by taking 200 samples. This research was conducted using path analysis and Sobel test to see the indirect effect. Before the path analysis is carried out, the reliability, validity and classical assumption tests are carried out first to see if the data obtained is appropriate for further analysis. The result show that social media influencers can influence generation $Z$ brand loyalty and purchase intentions are able to mediate social media influencers and generation $Z$ brand loyalty.
\end{abstract}

Keywords $\quad$ social media influencer; generation Z; purchase intentions; brand loyalty

\section{INTRODUCTION}

Nowadays, society is very dependent on social media, and most people move their interaction to these platforms (i.e., Instagram, Twitter, Facebook, and Linkedln). In 2019, there are 3,5 billion social media users all worldwide, as reported by Ortiz-Ospina (2019). This shows an increase of more than $45 \%$ of the current population, and Asians became the number one social media users (J. Clement, 2020).

With more social networking, marketers are turning to social media to engage with potential customers and expected to increase social media advertising spending to $\$ 102$ billion in 2020 , up from $\$ 89$ billion in 2019 (Zote, 2020). Despite spending much money, marketers see that their investment returns also increase through social media marketing. $82 \%$ of marketers concur that social media marketing is presently centered on their commerce (Hutchinson, 2016).

There are several digital marketing channels available today, one of which is influencer marketing (Sudha \& Sheena, 2017). Formerly, sports and entertainment celebrities have been utilized in several businesses as powerful marketing strategies. The popularity of celebrities fascinates customers to think about the endorsed product. Today, influencer marketing has become a prevalent way for a marketer to promote their brands, items, or services by displaying a good image of influencers on items or brands to attract the attention of followers to buy or use endorsed products or services (Schouten et al., 2020).

In this era, it is uncommon to discover individuals who are not engaged in social media, particularly generation Z. Generation $Z$ is a very tech-savvy person. So, it is possible to attract their attention using social media marketing. $85 \%$ of Generation Z know about new products through social media and are not afraid to buy things online. By understanding how Generation Z uses social media to find out about various products, is a way to engage them with the right platform and right message (Fontein 2019). Practically half $(44 \%)$ of Generation Z has settled on a buying choice, dependent on a social influencer's suggestion. $70 \%$ of Generation Z follows at least one influencer on Instagram or YouTube (Williams 2020). So, influencer exposure is particularly significant in associating with Gen Z, who will, in general, be progressively hard to 
reach through usual media channels like TV and print.

For several years, there has been some research on how social media influencer influences post-purchase behavior (Liu et al. 2020; Gunnarsson et al. 2018; Dulek and Aydin 2020). However, despite the increment in observational research into the topic of social media, there is still little understanding of how social media influencers affect generation Z toward brand loyalty. This is exceptionally imperative since the highest holders of online buyers are youthful people (Gauthier 2018).

Having loyal customers is an expectation for every company because it will bring advantages to the company. According to Sari (2014), loyalty increased profitability through increased revenue, reduced costs of acquiring customers, and lower customer sensitivity to price. A loyal customer makes re-purchases, persuades others, and shows immunity to competitors (Anggraini, 2015). Before becoming loyal, customers usually tend to have an intention to buy the product.

Purchasing intention is the level of a respondent's propensity to act before a buying decision is implemented. Purchasing intention is derived from a learning process and a thought process that forms a perception (Sartika, 2017). According to research conducted by Andreti et al. (2019), several factors that influence buying intention include product quality, price, and promotion. Meanwhile, based on Rizki (2013), buying intention affects consumer loyalty.

Many studies have examined how the influence of social media influencers on brand loyalty and purchase intention. Such as research by Amalina (2016), which examined the effect of social media marketing on brand loyalty in the category of isotonic beverage industry, research conducted by Rachmy (2019), which examined social media influencers on purchase intention in the cosmetic category, and research conducted by Laksamana (2018) examined the effect of social media toward purchase intention and brand loyalty in retail banking. However, no research examines the influence of social media influencers on brand loyalty and purchases intention generation $Z$ in the clothing field. According to Reyta (2018), social media influencer opinion influences the shift in Indonesian people's consumer behavior. Several studies about social media marketing were already carried out in Indonesia (Karman, 2015; Permatasari \& Kuswadi, 2017), but more particularly in social media influencers still uncommon.

To address the gap, this study investigates the effects of celebrity endorsement on purchase intentions and brand loyalty of Generation Z's focus on the clothing purchase decision. As one of the primary purchasing decisions that youthful buyers begin making independent is clothing purchases (Paakkari, 2016).

Thus, this study has two questions that are addressed: 1) does social media influencer influence generation $Z$ brand loyalty on clothing purchases?; and 2) does purchase intention mediate the relationship between social media influencers and brand loyalty on clothing purchases?.

\section{LITERATURE REVIEW AND HYPOTHESES DEVELOPMENT}

\section{Social media influencer (SMI)}

Even though social media is very well known today, scholastic definitions are still rare. Glucksman (2017) defined social media influencer as "a new type of independent third-party endorser who shapes audience attitudes through blogs, tweets, and the use of other social media." While, a study by Khamis et al. (2017) states that social media influencers is a type of micro-celebrity who practices self-presentation on social media, fulfilled through the creation of a web picture and the utilize of that picture to pull in and lock in with an expansive number of followers.

\section{Purchase intentions}

Purchase intentions is consumers plan to buy products or services because of their needs that cause attitudes and perceptions of the product (Sohail et al., 2015). Knowing the purchase intention of a brand is exceptionally imperative since it can improve long-term relationships with consumers. Brand attitude, brand image, quality, knowledge about the brand, attributes, and brand loyalty are some of the brand's dimensions upon which purchase intention is predisposed (Tariq et al., 2013). These functions have a strong influence on the purchase intention of customers. 


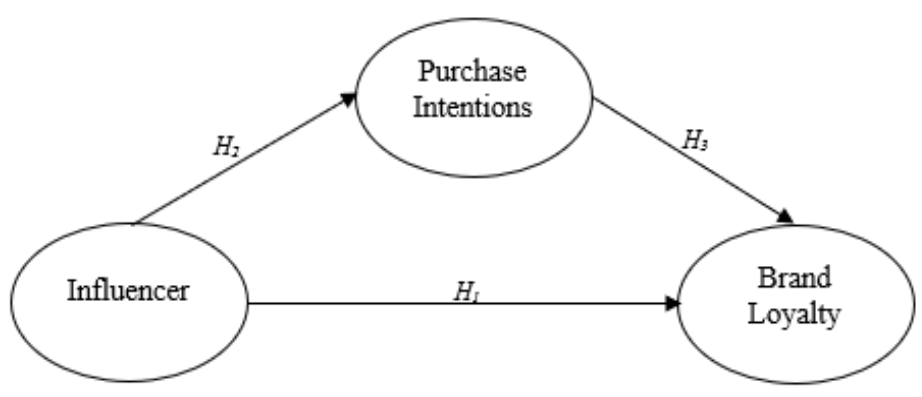

Figure 1.

The conceptual research framework

\section{Brand loyalty}

Brand loyalty is an emotional or psychological attachment to a brand (So et al., 2013). Those who show loyalty to a brand tend to show a positive attitude and a deep commitment to it, and direct them to support it (Lobschat et al., 2013). Other scholars defined brand loyalty as the choice of consumers for one brand over another (Yoo \& Donthu, 2001). According to Miller (2017) loyalty to a brand has been formed when the brand is irreplaceable in the heads of consumers. When social media user becomes emotionally and psychologically attached to a brand, they will tend to share that information with others (Yeh \& Choi, 2011).

\section{Social media influencer and purchase intentions}

Studies demonstrated that participation in a firm's social media activities positively affects someone's purchase intentions. For example, Erkan \& Evans (2016) studied the impact of quality, validity, value, and selection of data in social media marketing is the main factor influencing purchase intentions. According to Schivinski \& Dabrowski (2016), social media influencer has a substantial impact on consumer purchase intention. The influence exerted by influencers on a brand is enormous (Francalanci \& Metra, 2015). Influencers give endorsers and good reviews for a brand that will bring a high spike in sales of the goods. Therefore marketers are willing to spend a lot of money to recruit influencers to promote their brands (Sudha \& Sheena, 2017). Chung \& Cho (2014) found that social media users believe that influencer can start and improve purchase intentions. However, overall, influencer's artificial content for a brand has a more substantial impact on consumer buying behavior (Sudha \& Sheena, 2017).

\section{H1: Social media influencer have positive effect on purchase intention of generation $Z$.}

\section{Social media influencer and brand loyalty}

One of the main goals of the organization is to build and maintain brand loyalty because this is believed to increase revenue and market share (Schivinski \& Dabrowski, 2016). Brand loyalty reflects the state of loyal consumers because they hold their strong preferences towards a brand through confidence. This, in turn, leads to the final step of purchasing and repurchasing (Erdoğmuş \& Çiçek, 2012). Social Media Influencer is known as one of the most popular mediums of marketing. It is even considered as a winning strategy to build the uniqueness of a brand. Marketers' expectations of the endorsement carried out by celebrities can transfer positive meaning to the brand not only to attract attention (Audi et al., 2015). Based on the data from Hutchinson (2016) most marketers spend their money on advertising. Most of them use influencers and celebrity endorsements to promote their brands. Ismail (2017), in their research, concluded that the amount of budget spent on promotion was positively associated with brand loyalty on social media. Another study examining influencers and their effects on loyalty gave the same results (Audi et al., 2015).

H2: Social media influencer have positive effect on brand loyalty of generation $Z$. 
Table 1.

Measurements

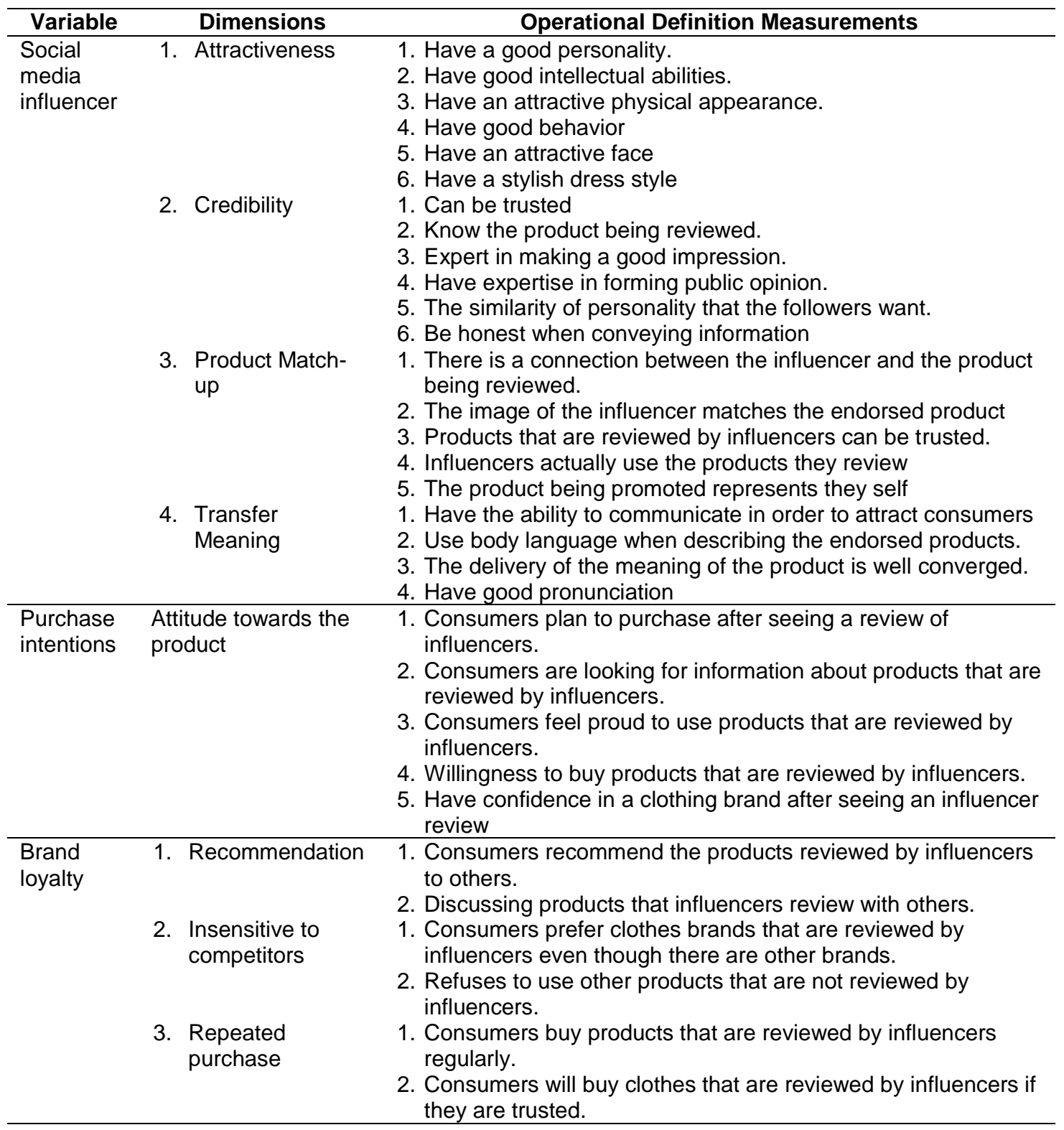

\section{Social media influencer, purchase intentions and brand loyalty}

Consumers buy a brand or product based on its quality, image, and price (Suhaily \& Darmoyo, 2017). The way marketers attract customers should also be considered. Marketing techniques with influencers are believed to be able to make a product or brand stay in the consumer's brain. it has been found that the experience of purchasing remains in consumers' mindset for a long time (Bashir, 2013).
The memories obtained when viewing an influencer's review create a feeling of curiosity and a great purchase intention towards the product or the brand. Then a good buying experience can create loyal customers. With an engaging experience, consumer product trust increases, leading consumers to the next purchase and not hesitate to talk about the product to others.

The support of social media influencers has long been used by companies to increase a brand's attractiveness. The more credible the influencer, the more consumer loyalty will increase. However, there are 
studies that state influencer does not directly affect brand loyalty but must go through a mediating variable (Stephanie, et al, 2013). The effect of celebrities to encourage the creation of loyal customers can also be achieved through consumer purchase intentions. If the influencer is credible, it will encourage the creation of purchase intentions and, in the end, will foster a feeling of loyalty in the minds of consumers.

H3: There is an influence between social media influencer and generation $Z$ brand loyalty with purchase intention as a mediating variable.

\section{METHODS}

This study is conducted by quantitative approach. The population of this research is all Indonesian citizens who enjoy social media. The sampling method in this study uses a purposive sampling technique. Purposive Sampling Technique can be said as deliberately taking specific samples according to the sample's criteria, so the selection of samples cannot occur accidentally based on whoever meets the researchers but must follow the predetermined criteria (Elder, 2009). Criteria for the respondents in this study are: 1) the minimum age of respondents is 17 and the maximum age is 23 years old (Generation Z); 2) men and women who enjoy social media Instagram; 3) men and women who follow at least one social media influencer.

As for the scale, this study used measurements that commonly employed to measure social media influencer, purchase intentions, and brand loyalty. As presented in Table 1, social media influencer was measured using 4 dimensions, purchase intention using 1 dimension, while brand loyalty using 3 dimensions.

The data obtained from online questionnaire that was distributed using a link via the message column on social media Instagram. The distribution of questionnaires was carried out using a Likert scale of 1 - 5 and the questionnaires use Bahasa since the target respondent is Indonesian. This study used a sample of 200 respondents obtained through the Google Forms.

\section{RESULT AND DISCUSSION}

As shown in Table 2, the respondents of this study was dominated by women with a
Table 2.

Respondent characteristics

\begin{tabular}{|c|c|c|}
\hline Category & Frequency & Percentage \\
\hline \multicolumn{3}{|c|}{ Gender } \\
\hline Male & 35 & $17.5 \%$ \\
\hline Female & 165 & $82.5 \%$ \\
\hline \multicolumn{3}{|c|}{ Age } \\
\hline $\begin{array}{l}\text { 17-20 Years } \\
\text { old }\end{array}$ & 34 & $17 \%$ \\
\hline $\begin{array}{l}\text { 21-23 Years } \\
\text { old }\end{array}$ & 166 & $83 \%$ \\
\hline \multicolumn{3}{|c|}{ Job } \\
\hline Student & 15 & $7.5 \%$ \\
\hline $\begin{array}{l}\text { University } \\
\text { student }\end{array}$ & 141 & $70.5 \%$ \\
\hline Workers & 36 & $18 \%$ \\
\hline Entrepreneur & 4 & $2 \%$ \\
\hline Others & 4 & $2 \%$ \\
\hline \multicolumn{3}{|c|}{ Influencer } \\
\hline Awkarin & 40 & $20 \%$ \\
\hline Arief & 20 & $10 \%$ \\
\hline \multicolumn{3}{|l|}{ Muhammad } \\
\hline Rachel & 23 & $11.5 \%$ \\
\hline \multicolumn{3}{|l|}{ Venya } \\
\hline Keanu & 10 & $5 \%$ \\
\hline Fadil Jaidi & 7 & $3.5 \%$ \\
\hline Others & 100 & $50 \%$ \\
\hline
\end{tabular}

presentation of $82.5 \%$, while the remaining $17.5 \%$ were male. This result shows that among Generation Z, women are more likely to follow social media influencers. Moreover, based on age, the respondent mostly from age between 21-23 years old, with percentage $83 \%$ which means people between that age are university student. Lastly, from the influencer classification, the the most followed influencer in this study was Awkarin (20\%).

Before the data were further analyzed, the validity and reliability tests will be carried out first. This test uses 200 respondents to ascertain whether the data to be measured has accuracy and precision (validity) and can be trusted (reliability). The first test that has been done is the validity test as shown in Table 4. The data is valid if the correlation coefficient of the questions in the variable is 
Table 3.

Descriptive statistics

\begin{tabular}{|c|c|c|c|}
\hline Variable & Dimension & Statement & Mean \\
\hline \multirow[t]{21}{*}{ Influencer } & \multirow[t]{6}{*}{ Attractiveness } & SMI1 & 4.58 \\
\hline & & SMI2 & 4.41 \\
\hline & & SMI3 & 4.24 \\
\hline & & SMI4 & 4.62 \\
\hline & & SMI5 & 3.98 \\
\hline & & SMI6 & 3.82 \\
\hline & \multirow[t]{6}{*}{ Credibility } & SMI7 & 4.76 \\
\hline & & SMI8 & 4.70 \\
\hline & & SMI9 & 4.62 \\
\hline & & SMI10 & 4.50 \\
\hline & & SMl11 & 3.49 \\
\hline & & SMI12 & 4.75 \\
\hline & \multirow{5}{*}{$\begin{array}{l}\text { Product } \\
\text { match-up }\end{array}$} & SMI13 & 4.43 \\
\hline & & SMl14 & 4.40 \\
\hline & & SMI15 & 4.30 \\
\hline & & SMI16 & 4.54 \\
\hline & & SMl17 & 4.37 \\
\hline & & SMI18 & 4.66 \\
\hline & \multirow[t]{3}{*}{ Meaning } & SMI19 & 4.62 \\
\hline & & SMI20 & 4.62 \\
\hline & & SMI21 & 4.71 \\
\hline \multirow{5}{*}{\multicolumn{2}{|c|}{ Purchase Intentions }} & $\mathrm{PI} 1$ & 4.49 \\
\hline & & $\mathrm{Pl} 2$ & 4.34 \\
\hline & & $\mathrm{PI3}$ & 3.76 \\
\hline & & $\mathrm{Pl} 4$ & 4.24 \\
\hline & & $\mathrm{PI} 5$ & 4.39 \\
\hline \multirow{6}{*}{\multicolumn{2}{|c|}{ Brand Loyalty }} & BL1 & 4.22 \\
\hline & & BL2 & 4.08 \\
\hline & & BL3 & 3.73 \\
\hline & & BL4 & 2.93 \\
\hline & & BL5 & 4.32 \\
\hline & & BL6 & 4.54 \\
\hline
\end{tabular}

greater than $0.138(\mathrm{~N}=200$ with $\alpha=5 \%)$. So, the data can be concluded as valid because the range of validity results is greater than 0.3494 .

The next test that has been done is the reliability test as shown in Table 4 . The data are reliable if Cronbach's Alpha of the thirtytwo empirical indicator is greater than 0.60 . The validity test results show that the data is reliable since the reliable coefficient is greater than 0.60. Meanwhile, Table 3 shows the descriptive statistic for variables in this study.

Path analysis is using in this study to analyze the hypothesis. The hypothesis will be accepted if the significance value is smaller than the alpha, which is 0.05 .
Table 4.

Validity and reliability result

\begin{tabular}{lcc}
\hline \multicolumn{1}{c}{ Variable } & $\begin{array}{c}\text { The range of } \\
\text { validity test } \\
\text { results }\end{array}$ & $\begin{array}{c}\text { Reliability } \\
\text { Coefficient }\end{array}$ \\
\hline $\begin{array}{l}\text { Influencer } \\
\text { Purchase }\end{array}$ & $0.33-0.743$ & 0.742 \\
intention & $0.522-0.735$ & 0.710 \\
Brand Loyalty & $0.599-0.789$ & 0.791 \\
\hline
\end{tabular}

To see the effect of mediating variable, the test will use the Sobel test. The Sobel test is used to see whether the mediated relationship yields a significant value. The mediation variable is significant because Sobel test value ( $z$ count) is greater than the $z$ table (1.98) with an alpha of $5 \%$.

The results of data analysis as shown in Table 5 suggests that the significance value of the test (interaction) is 0,000 , which is less than $0.05(<0.05)$. Thus, $\mathrm{H} 1$ is supported. The results as shown in Table 6 suggests that the significance value of the test (interaction) is 0.000 , which is less than 0.05 $(<0.05)$. Thus, $\mathrm{H} 2$ is supported.

The direct effect given by social media influencers on brand loyalty satisfaction is 0.480 . Meanwhile, the indirect effect of social media influencers through purchase intentions on brand loyalty is $0.274 \times 0.514$ $=0.140$. There is a partial mediation effect in this stage because the effect of purchase intentions on brand loyalty is significant with a significant value of $0.00<0.05$, and social media influencers on purchase intentions are also significant $0.00<0.05$. From the results of the Sobel test on $\mathrm{H} 3$, it can be seen that the calculated $z$ value of 5.811 is greater than the $z$ table, which is 1.98 . Thus, H3 in this study is supported.

\section{DISCUSSION}

\section{The effect of social media influencers on purchase intention}

This result proves that influencers can influence Generation Z's purchase intentions. In other words, the majority of consumers would buy the clothing items that the Social Media Influencer recommends. Social media influencers' ability to convince the audience and their honesty in providing 
Table 5.

Hypothesis 1 testing

Coefficients $^{a}$

\begin{tabular}{llccccc}
\hline & & \multicolumn{2}{c}{$\begin{array}{c}\text { Unstandardized } \\
\text { Coefficients }\end{array}$} & $\begin{array}{c}\text { Standardized } \\
\text { Coefficients }\end{array}$ & & \\
\cline { 3 - 5 } & Model & $\mathbf{B}$ & Std. Error & Beta & t & Sig. \\
\hline 1 & (Constant) & 2.355 & 2.454 & & 0.959 & 0.338 \\
& Influencer & 0.203 & 0.026 & 0.480 & 7.703 & .000 \\
\hline
\end{tabular}

a. Dependent Variable: Purchase Intention

Source: Primary Data (2020)

Table 6.

Hypothesis 2 and 3 testing

Coefficients $^{\mathrm{a}}$

\begin{tabular}{cccccc}
\hline & \multicolumn{2}{c}{$\begin{array}{c}\text { Unstandardized } \\
\text { Coefficients }\end{array}$} & $\begin{array}{c}\text { Standardized } \\
\text { Coefficients }\end{array}$ & $\mathbf{t}$ & Sig. \\
\cline { 2 - 6 } Model & $\mathbf{B}$ & Std. Error & Beta & & \\
\hline 1 (Constant) & -9.626 & 3.144 & & -3.062 & 0.003 \\
Influencer & 0.179 & 0.038 & 0.274 & 4.659 & 0.000 \\
Purchase & 0.792 & 0.091 & 0.514 & 8.724 & 0.000 \\
Intentions & & & & & \\
\hline
\end{tabular}

a. Dependent Variable: Brand Loyalty

Source: Primary Data (2020)

a product review gives a level of trust to generation Z. Moreover, as much as $55 \%$ generation $Z$ female are expressed interested in clothing product reviewed by influencer, and 52\% university student respondents aged 21-23 years stated that they decided to buy clothes after seeing influencer reviews on Instagram. This result is inversely proportional to the research Nurhandayani et al. (2019), which states that social media influencer have no significant effect on purchase intention.

This study's results are in line with previous research conducted by Hermanda et al. (2019), which states that social media influencers affect Instagram users purchase intentions. Using social media influencers as a marketing strategy is great for attracting the attention of Generation Z. With a habit of spending most of the time surfing on social media and a high impressionability, marketers should pursue influencer marketing strategies to attract Generation Z.

\section{The effect of social media influencers on brand loyalty}

With credibility, attractiveness, good connections between the influencer and the product being promoted, and a right way of conveying by an influencer about the products can make Generation Z loyal to a brand. The result of this study showed that influencers can increase Generation Z's loyalty to a product. The better an influencer is at explaining a product, the more difficult it will be for Generation Z to glance at other products not promoted by influencers. For marketers, brand loyalty is essential in terms of achieving marketing goals. Brand loyalty makes it difficult for competitors to enter the market (Apenes Solem, 2016).

This study proves that generation $Z$ like to discuss and recommend products reviewed by influencer to their relatives and decided to buy again at the same store on their next purchase. This result is probably because people feel bothered if their outfit same with other, so they will hide the shop where they buy (Moon \& Attiq, 2018). However, generation $Z$ really likes clothing 
brands that are promoted by influencers so that they will buy again at the same store on their next purchase. Another possible explanation is consumers' tendency to be attracted to adverts that make use of their favorite celebrities, as explained by $\mathrm{Ha}$ \& Lam (2016).

This research is in line with the research conducted by Jun \& Yi (2020) in which Social media influencers are positively related to brand loyalty. In a highly competitive environment, it is of paramount importance to have loyal customers. Thus, clothing marketers should consider using social media influencers when targeting generation $Z$. More satisfied customers can create longterm effects in building a loyal customer base, who can be future promoters of the brand. According to macansie\&... Generation Z likes to switch brands, making it difficult for companies to achieve loyalty. Interactivity carried out by influencers can increase the authenticity of the products they promote to make customers believe in the brand. Both interactivity, trustworthiness, and authenticity can create long-term memory in the consumer's mind, and do not hesitate to refer them to others.

\section{The effect of social media influencer on brand loyalty with purchase intention as a mediation}

There is a partial mediation from the results of data processing, where purchase intention as a mediator on brand loyalty is a significant dependent variable, and the influence of social media influencers as an independent variable on purchase intention is also significant. According to Baron and Kenny, if the effect of the dependent variable on the mediating variable is significant and the influence of the independent variable on the mediating variable is also significant, it can be said that the findings of this study support the effect of partial mediated.

In this study, it can be concluded that purchase intentions are strong enough to mediate the influence of social media influencers toward brand loyalty. This means that before becoming loyal, customers usually tend to be interested in buying the brand, social media influencers can be used to increase customer purchase intentions. The brand loyalty indicator in this study focuses not only on repeat purchases but also on increasing the number of purchases, recommending others, and telling positive things. As many as $52.5 \%$ of respondents in this study decided to buy clothing products after seeing influencer reviews, and after buying the products tend recommend and tell their colleagues. Sometimes they also buy products at the same store on their next purchase.

\section{CONCLUSION}

Social media influencers have a significant influence on the purchase intentions of generation $Z$. It can be said that use social media influencers can be one of the potential strategies to attract the $Z$ generation, as long as the chosen influencer not only has an attractive appearance but has high credibility. This study showed that most Generation $Z$ is more concerned with influencers' credibility than the appearance of being attractive. Marketers should choose the right social media influencer to endorse their products since good image influencers can affect the brand.

This study also showed that social media influencers significantly affect brand loyalty generation Z. Generation Z is identified as a generation that is very quickly bored. However, if they are given something more unique, they can become loyal customers. The use of an influencer can affect their beliefs, especially since Generation Z is a generation that is very close to social media.

The following conclusion is that purchase intention can mediate the relationship between influencer and brand loyalty. Influencer marketing has a positive impact on purchase intentions, which helps build brand loyalty as repurchasing from the same brand leads to commitment (Mao et al., 2014). Generation $Z$ tends to purchase a product after seeing a review from the influencer. If the influencer's information matches with expectation, then generation $\mathrm{Z}$ will show their loyalty even, they are not reluctant to recommend and discuss it with their closest people.

For the next study, there were several suggestions that could be implemented in further research. Firstly, most of the respondents in this study were Satya Wacana Christian University students, which is not able to represent all the $\mathrm{Z}$ generation in Indonesia. Therefore, future research can expand the object of research so that it can expand the scope of research or take objects from various other segments. Secondly, the study did not limit individual influencers but 
asked participants to remember the influencers they followed. Thus, differences may exist in influencer activity or follower motivation as the reach of the influencer mentioned by the subject cannot be controlled. Further research were also recommended to add other compatible variables that could be influenced by social media influencers such as brand awareness, brand image, and brand reputation, for produce better result. Because using social media influencers can increase the attractiveness of a brand, social media influencers are believed to increase branding with minimal costs, especially if the target consumer is the young generation.

\section{REFERENCES}

Amalina, A. (2016). Pengaruh Social Media Marketing Terhadap Brand Loyalty dengan Brand Trust Sebagai Variabel Intervening (Studi pada Follower Twitter Mizone MizonelD). Jurnal IImu Manajemen (JIM), 4(3).

Andreti, J., Suresh, K., Zhafira, N. H., \& Akmal, S. S. (2019). The analysis of product, price, place, promotion and service quality on customers' buying decision of convenience store: a survey of young adult in bekasi, west java, indonesia. International Journal of Advances in Management and Economics.

Anggraini, F. (2015). Pengaruh Brand Image Terhadap Loyalitas Pelanggan Pada Koran Harian Riau Pos. Jom Fisip, 3(1).

Apenes Solem, B. A. (2016). Influences of Customer Participation and Customer Brand Engagement on Brand Loyalty. Journal of Consumer Marketing. https://doi.org/10.1108/JCM-04-20151390

Audi, M., Masri, R. Al, \& Ghazzawi, K. G. (2015). The Effect of Celebrity Endorsement on Creating Brand Loyalty: An Application on the Lebanese Cosmetic Sector's Demand. International Journal of Business Management \& Economic Research.

Bashir, A. (2013). Consumer Behavior Towards Online Shopping of Electronics in Pakistan. Theses Master.

Chun, C. S., Meng, W., Wen, R., Wen, E., Lim, W. M., Tan, R. W., \& Teh, E. W. (2018). Impact of Social Media Influencer on Instagram User Purchase Intention: the Fashion Industry. Faculty of Business and Finance Department of Marketing.
Chung, S., \& Cho, H. (2014). Parasocial Relationship Via Reality TV and Social Media. https://doi.org/10.1145/2602299.26023 06

Elder, S. (2009). Sampling methodology. In ILO school-to-work transition survey: $A$ methodological guide (pp. 1-40).

Erdoğmuş, İ. E., \& Çiçek, M. (2012). The Impact of Social Media Marketing on Brand Loyalty. Procedia - Social and Behavioral Sciences. https://doi.org/10.1016/j.sbspro.2012.09 .1119

Erkan, I., \& Evans, C. (2016). The Influence of eWOM in Social Media on Consumers' Purchase Intentions: An Extended Approach to Information Adoption. Computers in Human Behavior. https://doi.org/10.1016/j.chb.2016.03.00 3

Francalanci, C., \& Metra, I. (2015). ContentBased Discovery of Twitter Influencers.

Glucksman, M. (2017). The Rise of Social Media Influencer Marketing on Lifestyle Branding: A Case Study of Lucie Fink. Elon Journal of Undergraduate Research in Communications.

Ha, N. M., \& Lam, N. H. (2016). The Effects of Celebrity Endorsement on Customer's Attitude toward Brand and Purchase Intention. International Journal of Economics and Finance. https://doi.org/10.5539/ijef.v9n1p64

Hermanda, A., Sumarwan, U., \& Tinaprillia, N. (2019). The Effect of Social Media Influencer on Brand Image, SelfConcept, and Purchase Intention. Journal of Consumer Sciences. https://doi.org/10.29244/jcs.4.2.76-89

Hutchinson, A. (2016). New Data Shows $82 \%$ of Marketers Believe Social Media Marketing is Now Core to Their Business. https://www.socialmediatoday.com/mar keting/new-data-shows-82-marketersbelieve-social-media-marketing-nowcore-their-business

Ismail, A. R. (2017). The Influence of Perceived Social Media Marketing Activities on Brand Loyalty: The Mediation Effect of Brand and Value Vonsciousness. Asia Pacific Journal of Marketing and Logistics.

https://doi.org/10.1108/APJML-102015-0154

J. Clement. (2020). Most popular social networks worldwide as of April 2020, ranked by number of active users. Statista. 
https://www.statista.com/statistics/2720 14/global-social-networks-ranked-bynumber-of-users/

Jun, S., \& Yi, J. (2020). What makes followers loyal? The role of influencer interactivity in building influencer brand equity. Journal of Product and Brand Management. https://doi.org/10.1108/JPBM-02-20192280

Karman, M. anastasia. (2015). The Impact of Social Media Marketing on Brand Equity toward the Purchase Intention of Starbucks Indonesia. IBuss Management. https://doi.org/10.18869/acadpub.aassj ournal.5.1.73

Khamis, S., Ang, L., \& Welling, R. (2017). Selfbranding, 'Micro-Celebrity' and the Rise of Social Media Influencers. Celebrity Studies. https://doi.org/10.1080/19392397.2016. 1218292

Laksamana, P. (2018). International Review of Management and Marketing Impact of Social Media Marketing on Purchase Intention and Brand Loyalty: Evidence from Indonesia's Banking Industry. International Review of Management and Marketing, 8(1).

Lobschat, L., Zinnbauer, M. A., Pallas, F., \& Joachimsthaler, E. (2013). Why Social Currency Becomes a Key Driver of a Firm's Brand Equity - Insights from the Automotive Industry. Long Range Planning. https://doi.org/10.1016/j.Irp.2012.11.004

Mao, Y., Zhu, J. X., \& Sang, Y. (2014). Consumer Purchase Intention Research Based on Social Media Marketing. International Journal of Business and Social Science.

Miller, J. (2017). The Importance of Brand Loyalty May. Randall \& Reilly. https://www.randallreilly.com/theimportance-of-brand-loyalty/

Moon, M. A., \& Attiq, S. (2018). Compulsive Buying Behavior: Antecedents, Consequences and Prevalence in Shopping Mall Consumers of an Emerging Economy. Pakistan Journal of Commerce and Social Science.

Nurhandayani, A., Syarief, R., Syarief, R., \& Najib, M. (2019). The Impact of Social Media Influencer and Brand Images to Purchase Intention. Universitas Brawijaya Journal of Applied Management (JAM), 17(4).

Ortiz-Ospina, E. (2019). The rise of social media. Our World in Data. https://ourworldindata.org/rise-of-socialmedia

Paakkari, A. (2016). Customer Journey of Generation $Z$ in Fashion Purchases. LAHTI UNIVERSITY OF APPLIED.

Permatasari, A., \& Kuswadi, E. (2017). The Impact of Social Media on Consumers' Purchase Intention: A Study of Ecommerce Sites in Jakarta, Indonesia. Review of Integrative Business and Economics Research, 6(1), 321-335.

Rachmy, F. S. (2019). Pengaruh Social Media Influencer terhadap Purchase Intention pada Merek Kosmetik Wardah dengan Brand Image sebagai Variabel Mediasi. Economic Journal, 7(2).

Rebelo, M. (2017). How Influencers`Credibility on Instagram is Perceived by Consumers and Its Impact on Purchase Intention. Catolica Lisbon Business \& Economics, 1-92.

Reyta, F. (2018). Do Indonesian Social Media Celebrity, Influencer and Opinion Leader Affect Shifting in Consumer Behavior? Advances in Social Science, Education and Humanities Research, 197, 446454.

Rizki, A. R. A. (2013). Analisis pengaruh kualitas produk, harga dan promosi terhadap loyalitas pelanggan dengan minat beli ulang sebagai variabel intervening (studi pada Shibuya Resto Citraland Mall Semarang). UDiNus Repository.

Sari, C. (2014). Pengaruh Loyalitas Pelanggan terhadap Profitabilitas pada sebuah Perusahaan Jasa Automotive (PT" X") di Surabaya. Business Accounting Review, 1(2), 26-38.

Sartika, D. (2017). ANALISIS FAKTOR-FAKTOR YANG MEMPENGARUHI MINAT BELI ULANG PRODUK YOU C 1000 SERTA DAMPAKNYA TERHADAP LOYALITAS KONSUMEN. Jurnal Penelitan Ekonomi Dan Bisnis, 2(1). https://doi.org/10.33633/jpeb.v2i1.2231

Schivinski, B., \& Dabrowski, D. (2016). The Effect of Social Media Communication on Consumer Perceptions of Brands. Journal of Marketing Communications. https://doi.org/10.1080/13527266.2013. 871323

Schouten, A. P., Janssen, L., \& Verspaget, M. (2020). Celebrity vs. Influencer endorsements in advertising: the role of identification, credibility, and ProductEndorser fit. International Journal of Advertising. https://doi.org/10.1080/02650487.2019. 1634898 
So, J. T., Parsons, A. G., \& Yap, S. F. (2013). Corporate Branding, Emotional Attachment and Brand Loyalty: The Case of Luxury Fashion Branding. Journal of Fashion Marketing and Management.

https://doi.org/10.1108/JFMM-03-20130032

Sohail, Y., Rasheed, F., \& Zia, A. (2015). Identifying the Factors Affecting Customer Purchase Intention. Global Journal of Management and Business Research: A Administration and Management Volume. https://doi.org/10.1111/j.13652621.1940.tb17194.x

Sudha, M., \& Sheena, K. (2017). Consumer Decision Process: Impact of Influencers in the Fashion Industry. SCMS Journal of Indian Management.

Suhaily, L., \& Darmoyo, S. (2017). Effect of Product Quality, Perceived Price and Brand Image on Purchase Decision Mediated by Customer trust (study on Japanese Brand Electronic Product). Jurnal Manajemen. https://doi.org/10.24912/jm.v21i2.230

Tariq, M. I., Rafay Nawaz, M., Nawaz, M. M., \& Butt, H. A. (2013). Customer Perceptions about Branding and Purchase Intention: A Study of FMCG in an Emerging Market. J. Basic. Appl. Sci. Res.

Yeh, Y. H., \& Choi, S. M. (2011). Mini-Lovers, Maxi-Mouths: An Investigation of Antecedents to eWOM Intention Among Brand Community Members. Journal of Marketing Communications. https://doi.org/10.1080/1352726090335 1119

Yoo, B., \& Donthu, N. (2001). Developing and Validating a Multidimensional Consumer-Based Brand Equity Scale. Journal of Business Research. https://doi.org/10.1016/S01482963(99)00098-3

Zote, J. (2020). 55 critical social media statistics to fuel your 2020 strategy. https://sproutsocial.com/insights/socialmedia-statistics/ 